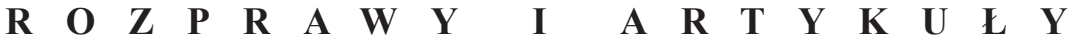

Prawo Kanoniczne $56(2013) \mathrm{nr} 3$

KS. TOMASZ JAKUBIAK

Papieski Wydział Teologiczny w Warszawie

\section{PROCEDURY DO PRZYJĘCIA ŚWIĘCEŃ DIAKONATU I PREZBITERATU}

Treść: Wprowadzenie. - 1. Dokumenty składane przez alumna przy przyjęciu do seminarium. - 2. Komisje ds. święceń i posług oraz dokumentacja skrutyniów. - 3. Sutanna, posługi, kandydatura, święcenia. - 4. Klerycy pochodzący z diecezji innych niż seminarium, w którym przygotowują się do święceń. - Podsumowanie.

\section{Wprowadzenie}

„Akt kanoniczny, poprzez który biskup diecezjalny, lub inny ordynariusz mający władzę, dopuszczają swojego wiernego do święceń, należy bez wątpienia do jednej z najbardziej delikatnych odpowiedzialności. Odpowiedzialność ta - z zachowaniem właściwych proporcji - dotyczy nie tylko dopuszczenia kandydatów do diakonatu i prezbiteratu, ale także obrzędu ustanowienia lektora i akolity" . Zanim alumn otrzyma święcenia, przechodzi integralną formację w seminarium, bowiem jako kandydat do święceń musi odznaczać się dojrzałością. Rozeznanie zdatności kandydata do święceń, jest bogatym i złożonym problemem, ponieważ „Bóg powołuje zawsze swoich kapłanów z określonych środowisk życia ludzkiego i kościelnego, które w sposób nieuchronny ich kształtują"2.

Przed przyjęciem święceń, kandydat odbywa przepisaną prawem próbę. Prawo kościelne wymaga, aby alumn ponadto odznaczał się wymaganymi przymiotami, nie był związany żadną nieprawidłowo-

${ }^{1}$ Kongregacja ds. Kultu Bożego i Dyscypliny Sakramentów, Pismo okólne do biskupów diecezjalnych i innych ordynariuszy mających władzę do dopuszczania do święceń, p. 1, 10.11.1997, Prot. N. 589/97.

2 JAN PAWEE II, Posynodalna adhortacja apostolska Pastores Dabo Vobis do biskupów, do duchowieństwa i wiernych o formacji kapłanów we współczesnym świecie, n. 5, 25.03.1992. 
ścią lub przeszkodą, wypełniał wymagania przepisane prawem kanonicznym $^{3}$. W przypadku, gdyby biskup mimo to na podstawie pewnych racji, miał wątpliwość, czy kandydat jest zdatny do przyjęcia święceń, nie powinien mu ich udzielać (Por. KPK 1983, kan. 1052 §3). W rozeznaniu zdatności kandydata do święceń kompetentny przełożony nie jest sam. Pomagają mu między innymi: rektor i wychowawcy seminarium, profesorowie, proboszczowie oraz inni mający kontakt z formowanym mężczyzną, tworząc czasami zespoły kolegialne doradcze.

Dopuszczenie do święceń, posług, kandydatury oraz przyjęcie do seminarium, jak większość czynności prawnych wymaga zebrania odpowiedniej dokumentacji. Ponieważ akty te są niezwykle ważne dla całego kościoła partykularnego, bowiem kapłan święcony jest dla Kościoła, dokumentacja gromadzona już od samego początku formacji alumna - a w zasadzie jeszcze przed przyjęciem do seminarium ${ }^{4}$ - jest dość obfita. Odzwierciedla on wnikliwy proces rozeznania przez biskupa diecezjalnego (oraz tych, którym to zadanie zostało również powierzone) zdatności alumna do przyjęcia święceń. Dokumentacja początkowo tworzy akta personalne kleryka, by z czasem stać się częścią akt osobowych duchownego. Kongregacja Kultu Bożego wypowiadając się na temat braków dokumentów badań alumna, przepisanych przez prawo kanoniczne, stwierdziła, że pozwalają one (braki) domniemywać, że badanie zdatności kandydata do święceń nie zostało przeprowadzone z należytą starannością 5 .

Celem niniejszego opracowania, jest przedstawienie złożonego procesu decyzyjnego towarzyszącego biskupowi diecezjalnemu przy

${ }^{3}$ Por. Codex Iuris Canonici auctoritate Ioannis Pauli PP. II promulgatus fontium adnotatione et indice analytico-alphabetico auctus. Liberia Editrice Vaticana 1989. Tłum. polskie: Kodeks prawa kanonicznego, przekład polski zatwierdzony przez Konferencję Episkopatu, Poznań 1984, kan. 1025, dalej jako KPK 1983).

4 „Pierwsze staranne badanie zdatności kandydatów powinno zatem mieć miejsce w momencie przyjmowania ich do seminarium; zdarza się bowiem nieraz, iż kandydaci przyjęci do seminarium, traktują każdy następny etap na drodze do kapłaństwa jako konsekwencję i naturalne przedłużenie tego pierwszego kroku." - KongREGaCJA DS. Kultu Bożego i Dyscypliny Sakramentów, Pismo okólne..., dz. cyt., p. 7.

5 Por. Tamże, n. 5. 
rozeznaniu zdatności kandydata do święceń od chwili przyjęcia mężczyzny do seminarium, aż po udzielenie jemu święceń prezbiteratu, oraz przybliżenie dokumentacji stanowiącej akta osobowe nowo wyświęconego prezbitera. Ma ono stanowić pomoc, dla wszystkich tych, którzy wspierają biskupa w tych aktach kanonicznych. Należy odnotować fakt, że autor niniejszej pracy ogranicza się jedynie do aspektu prawnego niniejszego zagadnienia, koncentrując się przede wszystkim na alumnach mających być włączonych do kleru diecezjalnego i diakonach diecezjalnych. Wzmianki o święceniu członków instytutów zakonnych lub stowarzyszeń życia apostolskiego, mogą pojawić się jedynie marginalnie $\mathrm{i}$ to tylko $\mathrm{w}$ takiej mierze, jakiej dotyczyłoby to biskupów diecezjalnych udzielających im święceń.

\section{Dokumenty składane przez alumna przy przyjęciu do seminarium}

Ratio institutionis sacerdotalis pro Polonia, zatwierdzone $\mathrm{dn}$. 26.08.1999 r. przez Kongregację ds. Wychowania Katolickiego stanowi, że kandydaci ubiegający się o przyjęcie do seminarium powinni przedłożyć rektorowi: prośbę o przyjęcie z podaniem motywów swojej decyzji, świadectwo chrztu i bierzmowania, wyciąg z aktu urodzenia ${ }^{6}$, świadectwo maturalne, świadectwo nauki religii, opinię proboszcza

${ }^{6}$ Przywołany dokument nie określa, jaki odpis aktu urodzenia winien zostać przedstawiony. W Polsce mamy dwa rodzaje odpisów: „Odpis skrócony aktu urodzenia” oraz „Odpis zupełny aktu urodzenia”. W tym miejscu warto zauważyć, że z zasady „Odpis skrócony aktu urodzenia” nigdy nie wykazuje faktu przysposobienia (adopcji) osoby, której dotyczy akt, zaś „Odpis zupełny aktu urodzenia” może, choć nie zawsze musi wskazywać na fakt przysposobienia osoby, której dotyczy akt. Są bowiem takie sytuacje, kiedy zgodnie z Prawem o aktach stanu cywilnego po przysposobieniu, sporzadza się nowy aktu urodzenia, a do dotychczasowego aktu urodzenia przysposobionego wpisuje się wzmianke dodatkowa. Dotychczasowy akt urodzenia przysposobionego nie podlega ujawnieniu i nie wydaje się z niego odpisów, chyba że zażada tego sąd $w$ zwiazku ze sprawa, w której uzna to za konieczne. W uproszczeniu oznacza to, że w „Odpisie zupełnym aktu urodzenia” nie będzie figurowała żadna wzmianka o przysposobieniu, a przysposabiający będą figurowali we wspomnianym dokumencie w miejscu rodziców biologicznych. - por. Ustawa z dnia 29 września 1986 r., Prawo o aktach stanu cywilnego, Dziennik Ustaw Rzeczpospolitej Polskiej 2011, nr 212, poz. 1264 (tekst jednolity ustawy). 
i katechety, świadectwo lekarza wskazanego przez seminarium o stanie zdrowia fizycznego i psychicznego ${ }^{7}$. Poza specjalnymi badaniami lekarskimi i psychologicznymi, wymagane są ponadto: opinia proboszcza o stanie zdrowia fizycznego, psychicznego i moralnego rodziny kandydata. W czasie dalszych lat formacji alumni powinni być pod stałą opieką lekarską . Rektor powinien w osobistej rozmowie z kandydatem zbadać jego dobrą intencję i wolność wyboru kapłaństwa. W tym calu również powinien zasięgnąć opinii proboszcza, rodziców kandydata i w miarę potrzeby także innych osób?

Co się tyczy próśb, podań, itp., na marginesie należy zauważyć, że dokumenty te, podobnie jak i inne oficjalne pisma powinny być podpisywane wszystkimi imionami. Nagminnie się zdarza, że osoby posiadające dwa imiona podpisują się tylko jednym. Dokumenty, podania, powinny być pisane piórem, a nie ich imitacjami, gdyż ze względu na swój charakter powinny być czytelne przez „wieki”.

Zgodnie z załącznikiem nr I pisma okólnego Kongregacji Kultu Bożego i Dyscypliny Sakramentów z 10 listopada 1997 roku $^{10}$, w dokumentacji alumna powinny się znaleźć następujące dokumenty. (Wydaje się, że większość z nich powinna być zgromadzona na samym początku formacji). Dokumentami tymi powinny być: świadectwo kanonicznego małżeństwa rodziców (jeśli możliwe - uzasadnione jest przedłożenie dokumentu przy przyjęciu do seminarium); dokument potwierdzający przyjęcie przez kandydata chrztu i bierzmowania; ${ }^{11}$ zaświadczenie o odbytych studiach (jeśli takowe były; RISP wymagało tylko świadectwa maturalnego; wydaje się, że uzasadnione jest

${ }^{7}$ Congregatio de Institutione Catholica, Decretum, 26.08.1999 r., w: Zasady formacji kapłańskiej w Polsce, Częstochowa 1999, s. 11-12; Ratio institutionis sacerdotalis pro Polonia, p. 129, zatwierdzone dn. 26.08.1999 r. przez Kongregację ds. Wychowania Katolickiego, w: Zasady formacji kapłańskiej w Polsce, Częstochowa 1999, s. 80, (dalej jako RISP).

8 Tamże, n. 133.

9 Tamże, n. 135. (Nie ma pewności, w którym etapie formacji ten wymóg należy realizować).

${ }^{10}$ Por. Kongregacja ds. Kultu Bożego i Dyscypliny Sakramentów, Pismo okólne..., dz. cyt., Załącznik I.

${ }^{11}$ Por. KPK 1983, kan. $241 \S 1,1033,1050$ n. 3. 
przedłożenie dokumentu przy przyjęciu do seminarium); świadectwa cywilne mogące mieć związek z formacją (np. o służbie wojskowej; RISP nic na ten temat nie stanowi); zaświadczenie o stanie zdrowia; ${ }^{12}$ pisemną relację rektora domu, w którym kandydat odbył ewentualnie w przeszłości jakiś okres formacji (konieczne jest przedłożenie dokumentu przy przyjęciu do seminarium); ${ }^{13}$ listy polecające kapłanów,

${ }^{12}$ Por. KPK 1983, kan. 241 §1, 1029. Zaświadczenie lekarskie o stanie zdrowia złożone przy przyjęciu do seminarium powinno zostać uzupełnione o kolejne dokumenty w czasie dalszej formacji. Kongregacja ds. Kultu Bożego i Dyscypliny Sakramentów w Liście okólnym..., Załącznik I, p. 8 stwierdza, że ocena psychologa, wymagana jest jedynie wtedy od kandydata do święceń, gdy zachodzi poważny powód.

${ }^{13}$ Por. Zgodnie z KPK 1983, kan. 241 \$3 przy przyjęciu wydalonych z innych seminariów lub instytutów zakonnych (a więc nie tylko „byłych” kleryków diecezjalnych lub zakonnych, ale również tych którzy po rozpoczęciu nowicjatu wystąpili z instytutu na prawie papieskim bądź diecezjalnym- por. KPK 1983, kan. 646) wymagać należy zaświadczenia właściwego przełożonego o przyczynach wydalenia lub odejścia kandydata ubiegającego się o przyjęcie do seminarium (dokument ten należy dołączyć do akt alumna). RISP w p. 138-141 rozszerzyło zakres wymagań w stosunku do alumnów zmieniających seminarium lub dom formacji. W sprawie przejścia alumnów do innego seminarium obowiązują zasady wydane przez Konferencję Episkopatu Polski. Ze słusznych powodów alumni mogą po rozpoczęciu studiów prosić o przyjęcie do innego seminarium (np. w związku z przeniesieniem rodziców do innej diecezji, rozeznanym powołaniem do życia zakonnego, itp.) Alumni wydaleni z seminarium diecezjalnego albo odchodzący dobrowolnie w sytuacji „zagrożenia”, nie mogą być przyjęci do innego seminarium. W wypadkach wątpliwych o przyjęciu decyduje biskup diecezjalny seminarium, które przyjmuje wydalonego, po dokładnym zbadaniu przyczyny wydalenia i w porozumieniu z biskupem diecezjalnym seminarium, które wydaliło alumna. (A więc nie tylko potrzebne jest zaświadczenie, o którym w kan. 241 §3 KPK 1983, ale również ,jakieś” porozumienie z biskupem diecezjalnym seminarium, które wydaliło alumna, bądź zamierzało go wydalić - dokument ten należy dołączyć do akt alumna). Alumni wydaleni z seminarium zakonnego nie mogą być przyjęci do seminarium diecezjalnego bez zgody Przewodniczącego Konferencji Episkopatu. (Zgoda ta zgodnie z kan. 127 §1 KPK 1983 potrzebna jest do ważności aktu przyjęcia alumna do seminarium - powinna również znaleźć się w dokumentach alumna. Warto nadmienić, że mowa jest w ostatnim zdaniu o wydalonych z seminarium zakonnego a nie w ogólności o wydalonych z instytutu).

Według przywołanego listu okólnego Kongregacji w przypadku, gdy dany kandydat pochodzi z innej diecezji, innego zgromadzenia, czy instytutu życia konsekrowanego, bądź też na jakimś etapie drogi do kapłaństwa otrzymał formację w innym domu, należy bacznie zwrócić uwagę na właściwe motywy dokonanych przez niego zmian. 
którzy pomagali kandydatowi rozpoznać powołanie ${ }^{14}$. W dokumentacji powinien się znaleźć również, arkusz z danymi personalnymi i rodzinnymi kandydata wraz z dołączoną fotografią ${ }^{15}$.

Statut Wyższego Metropolitalnego Seminarium Duchownego św. Jana Chrzciciela w Warszawie, nadany przez Kardynała Józefa Glempa Arcybiskupa Metropolitę Warszawskiego w dniu 18.12.1997 r. (art. 89), stanowi, że kandydaci do seminarium duchownego oprócz wspomnianych dokumentów powinni przedłożyć: własnoręcznie napisany życiorys, cztery fotografie. Co do świadectwa chrztu dokument ów precyzuje, że ma być ono ,aktualne”, jednakże nie określa, co to tak naprawdę ów termin znaczy. Pomocnym w zrozumieniu tego określenia (aktualne) może się okazać Instrukcja Episkopatu Polski o przygotowaniu do zawarcia matżeństwa w Kościele Katolickim. Zgodnie z kan. 19 kodeksu Jana Pawła II, ,jeśli w określonej sprawie brak wyraźnej ustawy, powszechnej lub partykularnej, albo prawa zwyczajowego sprawa - z wyjątkiem karnej - winna być rozstrzygnięta z uwzględnieniem ustaw wydanych w podobnych sprawach, ogólnych zasad prawnych z zachowaniem słuszności kanonicznej, jurysprudencji, praktyki Kurii Rzymskiej oraz powszechnej i stałej opinii uczonych". A zatem w punkcie 44 przywołanej przed chwilą instrukcji czytamy: „Metryka bowiem w pełnym wypisie jest nie tylko dowodem przyjęcia chrztu ale o ile jest świeżej daty, tzn. wydana nie wcześniej niż sześć miesięcy temu również stwierdzeniem stanu wolnego". Wydaje się zatem, w analizowanym powyżej przypadku, uzasadnionym przyjęcie, że przez metrykę chrztu ,aktualną” można uznać metrykę wypisaną nie wcześniej niż sześć miesięcy przed zgłoszeniem się kan-

(Przy przyjmowaniu do seminarium kleryków z seminariów zakonnych należy wziąć pod uwagę również wytyczne zawarte w Instrukcji dla Konferencji Episkopatów na temat przyjmowania do seminariów kandydatów przychodzacych $z$ innych seminariów lub rodzin zakonnych z dn. 9 października 1986 r. i 8 marca 1996 r.).

${ }^{14}$ Por. Paulus VI, Motu proprio Sacramentum diaconatus ordinem, III. 12, 18.06.1967, AAS 59(1967), s. 697-704 (dalej, jako SDO). [Acta Apostolicae Sedis. Commentarium Officiale, Typis Polyglottis Vaticanis 1909], (dalej jako AAS).

${ }^{15}$ Por. Kongregacja ds. Kultu Bożego i Dyscypliny Sakramentów, Pismo okólne..., dz. cyt, Załącznik I, p. 5. 
dydata na rozmowę kwalifikacyjną, bądź też przed złożeniem przez niego dokumentów wymaganych do przyjęcia do seminarium, jeśli te dwie daty nie są tożsame. Metryka „aktualna” jest też dokumentem kościelnym pozwalającym stwierdzić stan wolny przyszłego alumna. $\mathrm{Na}$ marginesie w tym miejscu należy zaznaczyć, że wydaje się koniecznym przed przyjęciem przez alumna święceń diakonatu (ewentualnie złożeniem ślubów wieczystych - lub innych o podobnym skutku - w przypadku alumnów niediecezjalnych) wystąpienie przez rektora seminarium do proboszcza parafii chrztu alumna o metrykę chrztu ,aktualną" w pełnym odpisie. Wcześniej złożona przy przyjęciu kandydata do seminarium metryka chrztu nie pozwala już stwierdzić stanu wolnego. Mało który proboszcz ma w zwyczaju zaznaczanie w uwagach aktu chrztu fakt wydania metryki ,dla celów seminarium duchownego", tym bardziej że takiego wymogu prawnego nie ma. A zatem (teoretycznie - bez wchodzenia w szczegóły) mogłaby się zdarzyć sytuacja, kiedy to alumn po przyjęciu do seminarium, a przed diakonatem, wstąpi w związek małżeński.

W przypadku metryk chrztu, szczególną uwagę należy również zwrócić na ich zgodność z dokumentami państwowymi, np. przedłożonym odpisem aktu urodzenia z USC. Przykładowo - czy zgadza się wypisana w metryce ilość imion kandydata do święceń i jego rodziców z aktem urodzenia USC. W przypadku różnic należy zastosować zwaną w Archidiecezji Warszawskiej ,procedurę zmiany w aktach metrykalnych", zgodnie z którą na dokonanie zmiany w akcie chrztu, proboszcz - po przedłożeniu odpowiednich dowodów - musi uzyskać zgodę ordynariusza miejsca. Tymi dowodami oprócz „Odpisu skróconego aktu urodzenia” „Odpisu zupełnego aktu urodzenia”, mogą być inne dokumenty państwowe poświadczające zmianę danych osobowych, jak np. postanowienie sądowe, decyzja kierownika USC, itp. Problem może się pojawić przy tzw. pełnej adopcji, gdzie „Odpis zupełny aktu urodzenia" nie zawiera informacji o zmianach personalnych - choć i w tym przypadku istnieją pewne rozwiązania, które z pewnością będzie w stanie zasugerować każda Kuria diecezjalna, spotykająca się niejednokrotnie z podobnymi problemami. 


\section{Komisje ds. święceń i posług oraz dokumentacja skrutyniów}

Zgodnie ze wspomnianymi wcześniej zaleceniami Stolicy Apostolskiej w każdej diecezji powinna istnieć grupa kapłanów tworzących „Komisję ds. święceń i posług”, która na kolegialnych zebraniach oceniałaby dotychczasową postawę każdego z kandydatów do święceń i posług ${ }^{16}$. Choć normy zawarte załączniku III p. 1-9 według obowiązującego ustawodawstwa można fakultatywnie wprowadzać w życie w diecezjach polskich, należy podkreślić, że komisja ta ma niezwykle ważne znaczenie przy uzyskaniu przez biskupa diecezjalnego pewności moralnej, co do zdatności kandydatów do święceń i posług. Ostatecznie to biskup lub kompetentny przełożony odpowiedzialny jest za dopuszczenie kandydatów do święceń ${ }^{17}$. Należy pamiętać, że ojcowie duchowni, związani ścisłą tajemnicą dotyczącą treści prowadzonych rozmów z alumnami, nie mogą zabierać głosu w sprawie dopuszczania do święceń lub ich wstrzymywania. Ojcowie i spowiednicy nie mogą wydawać również opinii o alumnach ${ }^{18}$. Zgodnie ze Statutem Wyższego Metropolitalnego Seminarium Duchownego św. Jana Chrzciciela w Warszawie, nadanym przez Kardynała Józefa Glempa Arcybiskupa Metropolitę Warszawskiego (art. 33), rektor musi wysłuchać zdania wicerektora przed dopuszczeniem alumnów do posług i święceń oraz opuszczeniem dyscyplinarnym Seminarium Duchownego.

Według załącznika II pisma okólnego do biskupów diecezjalnych i innych ordynariuszy majacych władze dopuszczania do święceń w sprawie: badania zdatności kandydatów, z dnia 10.11.1997, dokumentację skrutynium (lektoratu, akolitatu, diakonatu, prezbiteratu) powinny stanowić: pisemna prośba kandydata o dopuszczenie do danego obrzędu, która powinna mieć charakter osobisty oraz winna być napisana własnoręcznie (wyklucza się korzystanie z jakichkolwiek formularzy i tekstów fotokopiowanych); ${ }^{19}$ kolegialna opinia wychowawców; opinia własnego

${ }^{16}$ Kongregacja ds. Kultu Bożego i Dyscypliny Sakramentów, Pismo okólne..., dz. cyt., załącznik III.

${ }^{17}$ Por. KPK 1983, kan. 1029, 1051.

${ }^{18}$ Por. KPK 1983, kan. 240 §2, RISP p.108.

${ }^{19}$ Por. KPK 1983, kan. 1034 §1. Kongregacja Kultu Bożego i Dyscypliny Sakra- 
proboszcza kandydata; opinia kapłana, w którego parafii lub instytucji kandydat pomagał duszpastersko; inne opinie, które dyrektor formacji uzna za konieczne - np. z realizacji powierzonych alumnowi funkcji w życiu seminaryjnym, aktywności w kołach naukowych i wychowawczych, odbywania praktyki pastoralnej; ${ }^{20}$ opinia osobista - uzyskana z zachowaniem tajemnicy - niektórych kolegów z procesu formacyjnego, w której jasno i w sposób umotywowany, gdy tylko to jest możliwe, wyrażą pozytywne lub negatywne zdanie, co do zdatności kandydata ${ }^{21}$. Oprócz powyższych dokumentów, w dokumentacji skrutynium winna się znaleźć również szczegółowa osobista opinia rektora;22 a także -

mentów zauważa, że nie wolno przy jej redakcji korzystać z jakichkolwiek formularzy i tekstów fotokopiowanych.

${ }^{20}$ Por. RISP p. 134.

${ }^{21}$ Por. KPK 1983, kan. 1051, n. 2.

${ }^{22}$ Powinna ona odpowiadać głównym wytycznym przedstawionym w załączniku V Pisma okólnego do biskupów diecezjalnych i innych ordynariuszy mających władze do dopuszczania do święceń z dn. 10 listopada 1997 r. Kongregacji ds. Kultu Bożego i Dyscypliny Sakramentów. A zatem winna zawierać informacje o: 1. Zdrowiu fizycznym, zrównoważeniu psychicznym, dojrzałości osobowej; ewentualnych zjawiskach negatywnych występujących w przeszłości w rodzinie dotyczących zdrowia psychicznego, alkoholizmu, uzależnienia od narkotyków. 2. Cnotach naturalnych: szczerość, pracowitość, roztropność, uczciwość, stałość, duch poświęcenia i służby, umiejętność współżycia i wspólnej pracy (por. KPK 1983, kan. 245 §2, 275 §1). 3. Doktrynie: znajomość i umiłowanie doktryny katolickiej. Ortodoksja wiary. Stałe przekonania wobec pozycji przeciwnych Magisterium, promowanych dzisiaj przez określone grupy, np.: ideologie radykalne; święcenia kobiet; pewne opinie odnośnie moralności seksualnej i celibatu kościelnego. Zrozumienie natury i celów służby kościelnej. 4. Studiach: zainteresowanie studiami kościelnymi; oceny uzyskane na egzaminach z nauk kościelnych. Umiłowanie Pisma św. Zainteresowanie lekturą formacyjną. Troska o poznanie dokumentów Magisterium Kościoła. Zdolność wykonywania posługi Słowa (por. KPK 1983, kan. 762). 5. Posłuszeństwie: dyspozycyjność w przyjęciu tego, co zostało zlecone przez przełożonych. Zaufanie do hierarchii Kościoła. Przestrzeganie prawa kościelnego (por. KPK 1983, kan. 273). 6. Zachowaniu wobec dóbr materialnych: szacunek dla dóbr Kościoła; dystans; skromność w używaniu dóbr własnych; wrażliwość na biednych i cierpiących (por. KPK 1983, kan. 282 §1). 7. Celibacie: wyraźne przekonania co do jego natury i pozytywnego znaczenia. Pełna akceptacja celibatu, nie tylko, jako nieodzownego warunku dla otrzymania święceń. Wystarczająca dojrzałość uczuciowa i wyraźna, męska tożsamość seksualna (por. KPK 1983, kan. 1024). Zrównoważone zachowanie wobec kobiet: roztropność, kontrola 
przed święceniami - wynik zapowiedzi kanonicznych ogłoszonych odpowiednio wcześniej w parafiach dłuższego pobytu kandydata oraz inne dokumenty wymienione w dalszej części artykułu.

Na marginesie należy zauważyć, że zgodnie z RISP p. 98, rektor powinien pilnie badać dobrą intencję alumnów, ich zdolność moralną i intelektualną, zdrowie fizyczne i psychiczne oraz zdolność do znoszenia trudów kapłańskich i do wykonywania obowiązków duszpasterskich. Dla poznania osobistych kwalifikacji alumnów rektor powinien często sam z alumnami rozmawiać oraz chętnie wysłuchiwać oraz pilnie rozważać opinie i uwagi innych przełożonych, proboszczów, profesorów i lekarzy. RISP p. 99 ogranicza wymogi względem rektorów do przygotowania tak szczegółowej opinii. Według wspomnianego punktu - przedłożenie przez rektora biskupowi danych o rozwoju intelektualnym i duchowym, opinii wychowawców, zaświadczeń o ogłoszonych zapowiedziach, opinii proboszcza oraz świadectwa lekarskiego o stanie zdrowia kandydata, powinno mieć miejsce przed święceniami diakonatu i prezbiteratu. Norma zawarta w przywołanym

uczuć, delikatność w zachowaniu. Język, rozmowy, uzależnienie od telewizji (por. KPK 1983, kan. 277 §2; 285 §1-2) 8. Cnotach nadprzyrodzonych: duch wiary, miłość do Jezusa Chrystusa i do Kościoła, praktyka i duch modlitwy, miłość do Matki Bożej. Miłość do Eucharystii i codzienne uczestnictwo we Mszy Świętej. Celebracja Liturgii Godzin. Modlitwa różańcowa. Regularne przystępowanie do Sakramentu Pokuty. Gorliwość, apostolska. Umiłowanie liturgii. Duch wyrzeczenia i umartwienia (por. KPK 1983, kan. 245 §2, 246). 9. Rozwadze w ocenie sytuacji i w podejmowaniu decyzji praktycznych. Umiejętności rozsądnego planowania. 10. Duchu wspólnotowym: zdolność współżycia i wspólnego działania. Dyspozycyjność. Rozsądne organizowanie pracy. Wrażliwość na cierpienie i biedę innych. 11. Ewentualnych brakach: hipokryzja, egoizm, skąpstwo, karierowiczostwo, brak szacunku dla cnoty czystości i celibatu, arogancja, brak uczciwości, trudność charakteru, lenistwo, nieodpowiedzialność, upór, kompleks niższości, brak troski o drugiego człowieka, nadmierna aktywność, poszukiwanie wygód, poszukiwanie korzyści materialnych dla rodziny, agresywność, zależność od alkoholu i narkotyków, nienormalne tendencje uczuciowe, zachowania niezbyt męskie, pycha, indywidualizm. 12. Kierownictwie duchowym: czy regularne i z kim (por. KPK 1983, kan. 239 §2, 240 §1). Na zakończenie opinia powinna zawierać: 13. Inne uwagi. 14. Wynik ogólny odnośnie przyjęcia prośby.

Wiele uwag dotyczących przymiotów kandydatów do święceń można znaleźć w RISP - np. w punktach: 68, 76, 130, 179. 
punkcie 99 koresponduje z normą zawartą w kan. 1029 kodeksu Jana Pawła II, zgodnie z którą „do święceń należy dopuszczać jedynie tych, którzy - według roztropnej oceny własnego biskupa albo kompetentnego przełożonego wyższego - po rozważeniu wszystkich okoliczności, mają nieskażoną wiarę, kierują się prawidłową intencją, posiadają wymaganą wiedzę, cieszą się dobrą opinią, mają nienaganne obyczaje, wypróbowane cnoty, jak również inne przymioty fizyczne i psychiczne, odpowiadające przyjmowanemu święceniu". Oczywistym jest, że biskup wyrabia sobie roztropną opinię przed dopuszczeniem alumna do święceń na podstawie przedłożonych przez rektora danych.

\section{Sutanna, posługi, kandydatura, święcenia}

Zgodnie z RISP p. 132, alumni przywdziewają strój duchowny na początku trzeciego roku studiów.

O włączeniu do grona kandydatów ${ }^{23}$ do święceń decyduje biskup diecezjalny, jeśli osiągnie pewność moralną odnośnie do ich zdatności, opierając się na osobistym rozpoznaniu, bądź też na informacjach otrzymanych od wychowawców. Minimum miesiąc przed planowanym obrzędem liturgicznym biskup diecezjalny powinien przyjąć na piśmie, w formie dekretu prośbę ${ }^{24}$. Zasady tworzenia dekretu zostały uregulowane między innymi w tytule IV księgi I Kodeksu prawa kanonicznego z 1983 roku $^{25}$. Ci, którzy zostali przez śluby włączeni do kleryckiego instytutu życia konsekrowanego (i będą w nich przyjmo-

${ }^{23}$ Zgodnie z motu proprio Ad pascendum papieża Pawła VI w obrzędzie tym (włączenia do grona kandydatów do święceń), ten kto pragnie przyjąć diakonat i prezbiterat, wyjawia publicznie swoją wolę ofiarowania się Bogu i Kościołowi dla wykonywania przyjmowanych święceń. Kościół ze swej strony przyjmuje tę ofiarę, a tego, który ją składa, wybiera i wzywa, by przygotował się do przyjęcia święceń. W ten też sposób zostaje on prawnie włączony do grona kandydatów do diakonatu i prezbiteratu. - PAULus VI, Motu proprio Ad pascendum, 15.08.1972, AAS 64(1972), s. 534-540.

${ }^{24}$ Kongregacja Kultu Bożego i Dyscypliny Sakramentów, Pismo okólne..., dz. cyt., Załącznik III, p. 10.

${ }^{25}$ Więcej na temat dekretów można przeczytać między innymi w: J. KRUKOwSKI, Konkretne akty administracyjne, w: Komentarz do Kodeksu prawa kanonicznego, red. J. Krukowski, R. Sobański, t. 1, Poznań 2003, s. 94-160. 
wać święcenia) nie są przed diakonatem przyjmowani przez biskupa do grona kandydatów (Por. KPK 1983, kan. 1034).

Dokumentacja skrutinium poprzedzającego włączenie przez liturgiczny obrzęd do grona kandydatów ${ }^{26}$ wraz ze stosownym świadectwem kurii diecezjalnej potwierdzającym jego miejsce powinna zostać dołączona do akt osobowych kandydata do święceń ${ }^{27}$. Ze względu na znaczenie obrzędu przyjęcia kandydatów do diakonatu i prezbiteratu, nie należy łączyć ze święceniami ani z ustanowieniem lektorów i akolitów ${ }^{28}$. Od tego wymogu biskup diecezjalny może dyspensować w oparciu o normę zawartą w kan. 87 §1 Kodeksu prawa kanonicznego Jana Pawła II $^{29}$.

Na marginesie należy zauważyć, że zawsze w przypadku zwracania się z prośbą o dyspensę należy wskazać na słuszną przyczynę do udzielenia dyspensy. Brak przyczyny powoduje, że dyspensa jest udzielona nieważnie. O dyspensę może prosić kleryk, bądź rektor - słuszniejsze jest, gdy prosi rektor. Gdyby prosił kleryk, to prośba

${ }^{26}$ Por. Sacra Congregatio pro Cultu Divino, Ritus institutionis Lectorum et Acolythorum, admissionis inter candidatos ad Diaconatum et Presbyteratum, nec non sacri caelibatus ampetendi, eduntur, 03.12.1972, Prot. n. 1500/72, AAS 65(1973), s. 274-275.

${ }^{27}$ Por. Kongregacja ds. Kultu Bożego i Dyscypliny Sakramentów, Pismo okólne..., dz. cyt., Załącznik I, p. 12, 13.

${ }^{28}$ Por. Obrzęd przyjęcia kandydatów do diakonatu i prezbiteratu, n. 3, w: Pontyfikał Rzymski odnowiony zgodnie z postanowieniem Świętego Soboru Powszechnego Watykańskiego II wydany z upoważnienia papieża Pawła VI poprawiony staraniem papieża Jana Pawła II. Obrzędy święceń biskupa, prezbiterów i diakonów. Wydanie drugie wzorcowe, Katowice 1999, s. 315. (Pontyfikał Rzymski odnowiony zgodnie z postanowieniem Świętego Soboru Powszechnego Watykańskiego II wydany z upoważnienia papieża Pawła VI poprawiony staraniem papieża Jana Pawła II. Obrzędy święceń biskupa, prezbiterów i diakonów. Wydanie drugie wzorcowe, Katowice 1999; dalej jako Pontyfikał Rzymski).

${ }^{29}$ Więcej o dyspensowaniu można przeczytać w: J. P. McInTYRe, Dispensations, w: New Commentary on the Code of Canon Law, ed. J. P. Beal, J. A. Coriden, T. J. Green, Mahwah 2000, s. 126-136; E. BAURA, Dispensations, w: Exegetical Commentary on the Code of Canon Law, ed. Á. Marzoa, J. Miras, R. Rodríguez-Ocaña, English language ed. E. Caparros, P. Lagges, vol. I, Montreal - Chicago 2004, s. 644-676; P. LomBARDíA, Normy ogólne, w: Kodeks prawa kanonicznego. Komentarz. Powszechne i partykularne ustawodawstwo Kościoła katolickiego. Podstawowe akty polskiego prawa wyznaniowego, red. Piotr Majer, Kraków 2011, s. 120-125. 
powinna być przedłożona biskupowi diecezjalnemu zgodnie z kan. 238 §2 KPK 1983 za pośrednictwem rektora (Por. KPK 1983, kan. 61, 90). Według przywołanego kan. $238 \S 2$ kodeksu z 1983 r. w załatwianiu wszystkich spraw w imieniu seminarium występuje jego rektor, chyba że w odniesieniu do pewnych spraw kompetentna władza postanowi inaczej.

Obrzęd lektoratu powinno poprzedzać zwrócenie się kandydata $\mathrm{w}$ formie pisemnej do biskupa diecezjalnego z prośbą o udzielenie posługi lektora. Biskup diecezjalny przy dopuszczeniu do posługi powinien brać pod uwagę, uwzględniając wskazania Stolicy Apostolskiej, postępy kandydata $\mathrm{w}$ formacji wraz $\mathrm{z}$ jego przymiotami. Wydaje się konieczne, przeprowadzenie skrutinium według zaleceń Kongregacji Kultu Bożego i Dyscypliny Sakramentów. Dokumentacja ze skrutinium wraz ze świadectwem kurii diecezjalnej potwierdzającym udzielenie posługi lektoratu powinna zostać włączona do akt osobowych kandydata do święceń ${ }^{30}$. Decyzja biskupa o dopuszczeniu kandydata do posługi powinna być wyrażona w formie dekretu, wydanego przynajmniej miesiąc przed planowaną datą udzielenia posługi ${ }^{31}$.

Wszelkie procedury poprzedzające przyjęcie posługi akolitatu są tożsame z opisanymi powyżej przy okazji przyjęcia posługi lektoratu. Należy zwrócić uwagę, że ustawodawca nie wymaga zachowania jakiegokolwiek konkretnego odstępu czasu pomiędzy przyjęciem lektoratu a akolitatu. Jednak zgodnie z kan. 1035 §1 kodeksu Jana Pawła II, lektorat $i$ akolitat nie powinny być udzielane tej samej osobie w czasie jednej liturgii, gdyż osoba ma wykonywać posługę lektoratu przez jakiś czas. Od tego wymogu biskup diecezjalny może dyspensować w oparciu o normę zawartą w kan. 87 §1 Kodeksu prawa kanonicznego z 1983 roku.

Mówiąc o posługach wymaganych przed przyjęciem święceń, trzeba pamiętać, że błogosławienie chłopców do czytania Słowa Bożego, potocznie nazywane „lektoratem” oraz ustanowienie nadzwyczajnym

\footnotetext{
${ }^{30}$ Por. Kongregacja ds. Kultu Bożego i Dyscypliny Sakramentów, Pismo okólne..., dz. cyt., Załącznik I, p. 12, 13.

${ }^{31}$ Por. Tamże, Załącznik III, p. 10.
} 
szafarzem Komunii św. nie jest tożsame z przyjęciem lektoratu i akolitatu. Mamy tutaj tylko zbieżność terminów. W takim przypadku mężczyźnie, który przed seminarium otrzymał od biskupa bądź prezbitera błogosławieństwo do czytania Słowa Bożego, albo był ustanowiony nadzwyczajnym szafarzem Komunii św., należy udzielić posługi lektora i akolity ${ }^{32}$.

Może się również zdarzyć odmienna sytuacja. Alumn jeszcze przed seminarium mógł przyjąć posługę lektora bądź akolity ${ }^{33}$. W czasie obrad II Synodu Plenarnego biskupi podjęli decyzję, że akolitami w Polsce mogą być również mężczyźni świeccy, którzy ukończyli przynajmniej dwadzieścia pięć lat życia, cieszą się dobrą opinią, posiadają odpowiednie przymioty i są przygotowani do swych zadań poprzez odpowiednią formację. Według przywołanego dokumentu, posługę lektora można udzielać w wieku wcześniejszym. Na szczegółowe przepisy wykonawcze trzeba było jednak czekać do 2 października 2007 roku, kiedy to biskupi zebrani na 341 Zebraniu Plenarnym Konferencji Episkopatu Polski wydali Instrukcję w sprawie udzielania postugi Lektora i Akolity Świeckim Mężczyznom.

Przy okazji posług nasuwa się kolejne pytanie. Co się dzieje w przypadku, kiedy kleryk po przyjęciu wspomnianych posług odchodzi z seminarium? Zgodnie z przywołaną instrukcją, wykonywanie uprawnień właściwych akolicie odnośnie do Eucharystii, a także uprawnień właściwych lektorowi, ulega zawieszeniu z chwilą przerwania przez alumnów studiów seminaryjnych z jakiegokolwiek powodu, chyba że biskup diecezjalny inaczej postanowi ${ }^{34}$. Oznacza to zdaniem Z. Janczewskiego, że alumn wydalony z seminarium, lub opuszczający je z powodów zdrowotnych lub innych, czasowo - aż do powrotu do swojego seminarium, lub do przyjęcia go do innego, albo też na stałe

\footnotetext{
32 Por. Konferencja EpISKopatu Polski, Instrukcja Episkopatu Polski w sprawie udzielenia postugi lektora i akolity świeckim mężczyznom, 02.10.2007, p. 10. (Konferencja Episkopatu Polski - dalej jako KEP).

${ }^{33}$ Por. II Synod Plenarny, Liturgia Kościoła po Soborze Watykańskim II, n. 84, w: II Synod Plenarny (1991-1999), Poznań 2001, s. 206; KEP, Instrukcja w sprawie udzielania postugi..., dz. cyt., n. 15-16.

${ }^{34}$ Por. KEP, Instrukcja $w$ sprawie udzielania postugi..., dz. cyt., n. 17.
} 
(prowadząc później życie świeckie), nie może pełnić dwóch wymienionych posług ${ }^{35}$.

Od obowiązku przyjęcia posługi lektoratu i akolitatu biskup diecezjalny może dyspensować na podstawie normy zawartej w kan. 87 §1 KPK $1983^{36}$.

Jak zauważa ustawodawca w kan. $1031 \S 4$ KPK 1983 dyspensa ponad rok od wieku wymaganego do przyjęcia święceń diakonatu i prezbiteratu zarezerwowana jest Stolicy Apostolskiej. Wobec tego biskup diecezjalny może dyspensować kandydata do święceń od braku wymaganego wieku, ale nie więcej niż od roku życia. Prezbiteratu można udzielać tylko tym, którzy ukończyli dwudziesty piąty rok życia. Tych, którzy są przeznaczeni do prezbitreratu, można dopuścić do diakonatu dopiero po ukończeniu dwudziestego trzeciego roku życia ${ }^{37}$.

Wiek należy obliczać zgodnie z kan. 203 KPK 1983. A zatem, kto urodził się przykładowo 1 stycznia 1990 roku, będzie mógł w świetle obowiązujących przepisów bez dyspensy, przyjąć święcenia prezbiteratu dopiero dnia 2 stycznia 2015 roku. Rok, o którym mowa w kan. 1031 §4 KPK 1983 należy liczyć zgodnie z normą zawartą w kan. 202 $\S 2$ KPK 1983. Oznacza to, że ów rok należy rozumieć „kalendarzowo"38. Mamy tutaj do czynienia z czasem ciągłym w rozumieniu kan. $202 \S 1$ KPK 1983. Przykładowo, jak zauważa Kennedy, rok rozpoczynający się 1 stycznia 2000 roku liczy 366 dni, podczas gdy rok

${ }^{35}$ Por. Z. JANCZEwSKI, Instrukcja Episkopatu Polski w sprawie udzielania postugi lektora $i$ akolity świeckim mężczyznom z 2007 r. jako forma realizacji postanowień Kodeksu prawa kanonicznego z 1983 r., Prawo Kanoniczne 52(2009) nr 1-2, s. 144 (Prawo Kanoniczne - dalej jako PK); Z. Janczewski, Prawodawstwo Konferencji Episkopatu Polski i prymasów w zakresie sakramentów wtajemniczenia chrześcijańskiego, PK 40(1997) nr 3-4, s. 80.

${ }^{36}$ Por. F. LozA, Prerequisites for Ordination, w: Exegetical Commentary on the Code of Canon Law, ed. Á. Marzoa, J. Miras, R. Rodríguez-Ocaña, English language ed. E. Caparros, P. Lagges, Vol. III/1, Montreal - Chicago 2004, s. 970.

${ }^{37}$ Por. KPK. 1983, kan. $1031 \S 1$.

${ }^{38}$ Por. R. Sobański, Obliczanie czasu, w: Komentarz do Kodeksu prawa kanonicznego..., dz. cyt., t. 1, s. 294-296; T. PAwLuk, Prawo kanoniczne wedtug kodeksu Jana Pawła II. Zagadnienia wstęne i normy ogólne, T. I, Olsztyn 2002, s. 295-296. 
rozpoczynający się 1 stycznia 2001 roku liczy 365 dni ${ }^{39}$. Rok, o którym mowa w przywołanym kan. 1031 KPK 1983, należy także liczyć zgodnie z zasadą zawartą w kan. 203 §2 KPK 1983, która określa, że termin składający się z jednego lub więcej miesięcy lub lat kończy się z upływem ostatniego dnia tej samej daty (tzn. nie wliczanej). Jeśli miesiąc kalendarzowy nie ma dnia odpowiadającego początkowi terminu, kończy się on po upływie ostatniego dnia miesiąca (np. termin miesiąca, który zaczął się 31 stycznia, kończy się 28 względnie 29 lutego o godz. 24.00) ${ }^{40}$.

Zgodnie z kan. 1032 §1 KPK 1983 kandydaci do prezbiteratu mogą być dopuszczeni do diakonatu dopiero po ukończeniu piątego roku studiów filozoficzno-teologicznych. Jak zauważa Ratio Studiorum - Program studiów w wyższych seminariach duchownych $w$ Polsce, p. II.4.Gdo końca piątego roku studiów powinna zostać ukończona przez alumna praca dyplomowa. (We wspomnianym dokumencie mowa jest o ukończeniu pracy dyplomowej a nie obronieniu). Od tego wymogu biskup diecezjalny może dyspensować w oparciu o normę zawartą w kan. 87 §1 Kodeksu prawa kanonicznego Jana Pawła II.

Pomiędzy przyjęciem posługi akolitatu i diakonatem należy zachować odstęp minimum sześciu miesięcy (Por. KPK 1983, kan. 1035). Od przestrzegania tej normy biskup diecezjalny również może dyspensować powołując się na kanon 87 §1 kodeksu Jana Pawła II. Czas należy liczyć zgodnie z kan. 200-203 KPK 1983. A zatem, gdyby przykładowo kleryk otrzymał posługę akolitatu 2 lutego, mógłby już przyjąć święcenia diakonatu 3 sierpnia.

Pomiędzy przyjęciem diakonatu i prezbiteratu należy zachować odstęp minimum sześciu miesięcy (Por. KPK 1983, kan. 1031 §1). Od przestrzegania tej normy biskup diecezjalny również może dyspensować powołując się na kanon 87 §1 KPK 1983. Czas należy liczyć zgodnie z kan. 200-203 KPK 1983¹.

\footnotetext{
${ }^{39}$ Por. R. T. Kennedy, Prescription, w: New Commentary..., dz. cyt., s. 237.

${ }^{40}$ R. Sobański, Obliczanie czasu, w: Komentarz do Kodeksu prawa kanonicznego..., dz. cyt, t. 1, s. 296.

${ }^{41}$ Zasady naliczania czasu zostały przedstawione powyżej.
} 
Po zakończeniu okresu studiów, a więc po egzaminie ex univer$s a^{42}$, diakon powinien przez odpowiedni czas określony przez biskupa lub wyższego przełożonego, pracować w duszpasterstwie, wykonując święcenia diakońskie, zanim zostanie dopuszczony do święceń prezbiteratu ${ }^{43}$. Od tego wymogu biskup diecezjalny może dyspensować w oparciu o normę zawartą w kan. 87 §1 Kodeksu prawa kanonicznego z 1983 roku.

Dopuszczenie do święceń przez przełożonego poprzedza skrutinium. Oprócz dokumentów wymaganych na samym początku od mężczyzn zgłaszających wolę przyjęcia święceń oraz przy udzieleniu kandydatury i posług, o których wcześniej była już mowa, do dokumentacji skrutninium należy dołączyć: wynik zapowiedzi kanonicznych ogłoszonych odpowiednio wcześniej w parafiach dłuższego pobytu kandydata (zarówno przed diakonatem i prezbiteratem); ${ }^{44}$ zaświadczenie o należycie odbytych studiach; ${ }^{45}$ własnoręcznie sporządzone i podpisane przez alumna oświadczenia stwierdzające, że kandydat z własnej woli i dobrowolnie przyjmuje święcenia oraz że zawsze będzie wykonywał kościelną posługę, jednocześnie prosząc o dopuszczenie do święceń ${ }^{46}$, zaznaczając przy tym, że jest świadomy obowiązków i nakazów wiążących go na całe życie przez święcenia (przy święceniach diakonatu i prezbiteratu - KPK 1983, kan. 1036) - przede wszystkim obowiązku celibatu ${ }^{47}$ (ta deklaracja musi być wyrażona własnymi słowami, a nie kopiowana ze wzorca).

Po wydaniu wcześniej wspomnianego dekretu przez biskupa diecezjalnego o dopuszczeniu do święceń, przed przyjęciem święceń diakonatu,

${ }^{42}$ RISP, p. II.4.F.

${ }^{43}$ Por. KPK 1983, kan.1032 §2.

${ }^{44}$ Por. KPK 1983, kan. 1051, n. 2; Kongregacja ds. Kultu Bożego i Dyscypliny SAKramentów, Pismo okólne..., dz. cyt., Załącznik II, p. 8. Dla odmiany RISP p. 83 stanowi, że zapowiedzi przed święceniami powinny być głoszone we wspólnocie, w której zrodziło się powołanie alumna.

${ }^{45}$ Por. KPK 1983, kan. $10332 \S 3$.

${ }^{46}$ Por. KPK 1983, kan. 1026, 1028, 1036.

${ }^{47}$ Jeśli chodzi o obowiązek celibatu, to wyrażenie świadomości dotyczy mających przyjąć diakonat. 
kandydat powinien złożyć i podpisać wyznanie wiary, zgodnie z formułą zatwierdzoną przez Stolicę Apostolską przed ordynariuszem miejsca lub jego delegatem;"48 przysięgę wierności, zgodnie $\mathrm{z}$ formułą zatwierdzoną przez Stolicę Apostolską (przed diakonatem i prezbiteratem); ${ }^{49}$ złożyć napisaną własnoręcznie osobistą deklarację o swojej wolności w przyjęciu święceń w stopniu diakonatu i prezbiteratu oraz świadomości obowiązków i nakazów wiążących przez święcenia na całe życie (przede wszystkim trzeba uwzględnić obowiązek zachowania celibatu). Dokumenty te muszą zostać zachowane w aktach personalnych kandydata. Zaleca się, aby wymienione wyżej akty miały charakter publiczny i odbywały się w obecności wiernych, podczas celebracji mszy św., po homilii.

Co do warunku, o którym mowa w kan. 1037 KPK 1983, stanowiącym, że nieżonaty kandydat do stałego diakonatu, jak również kandydaci do prezbiteratu, nie powinni być dopuszczeni do diakonatu, zanim w przepisanym obrzędzie nie oświadczą publicznie wobec Boga i Kościoła, że podjęli obowiązek celibatu, rodzi się pytanie, kiedy powinno mieć miejsce złożenie takiego oświadczenia. Wśród kanonistów w tym temacie są różne opinie. Zdaniem Pawluka publiczne zobowiązanie się do zachowania celibatu zostało złączone z nowym obrzędem święceń diakonatu. Odbywa się ono po przedstawieniu kandydatów na diakonów ${ }^{50}$. Pogląd ten zdaje się potwierdzać Geisinger ${ }^{51}$. Odmiennego zdania jest M. Pastuszko. Jego zdaniem mimo, że kandydaci do święceń diakonatu w czasie święceń okazują, że są gotowi do życia w celibacie, to jednak zobowiązują się do zachowywania celibatu wcześniej przed święceniami ${ }^{52}$. Za tezą postawioną przez Pastuszkę, opowiadają się

\footnotetext{
${ }^{48}$ Ponieważ ustawodawca w kodeksie z 1983 roku w kan. 833, n. 6 wymaga od kandydatów do diakonatu złożenia wyznania wiary przed ordynariuszem miejsca lub jego delegatem, zatem trzeba pamiętać, że inni duchowni do przyjęcia wspomnianych aktów potrzebują delegacji.

${ }^{49}$ Por. Congregatio pro Doctrina Fidei, Professio fidei et iusiurandum fidelitatis in suscipiendo officio nomine Ecclesiae exercendo, 01.07.1988, AAS 81(1989), s. 104-106.

${ }^{50}$ Por. T. PAwluk, dz. cyt., s. 435.

${ }^{51}$ Por. R. J. Geinsinger, Orders, w: New Commentary..., dz. cyt., s. 1212-1213.

52 Por. M. PastuszKo, Sakrament święceń (kanony 1008-1054), Kielce 2008, s. 410-413.
} 
również inni kanoniści, np. Loza ${ }^{53}$. Z pomocą w rozwiązaniu problemu przychodzi dekret Kongregacji Kultu Bożego i Dyscypliny Sakramentów zawarty w Pontyfikale Rzymskim. Według niego obrzęd podjęcia obowiązku świętego celibatu, przygotowany przez Kongregację Kultu Bożego, zgodnie z postanowieniem listu apostolskiego papieża Pawła VI Ad pascendum z roku 1972, został obecnie wprowadzony do święceń diakonatu. Na mocy specjalnego zarządzenia papieża Jana Pawła II także kandydaci, którzy złożyli wieczyste śluby w jakimś instytucie zakonnym, są również obowiązani w czasie święceń diakonatu podjąć święty celibat, jako szczególną powinność prawnie związaną ze święceniami ${ }^{54}$. Zgodnie z Wprowadzeniem Ogólnym do wspomnianych obrzędów Konferencje Biskupów uzyskały prawo dostosowania obrzędów święceń do potrzeb poszczególnych regionów. Uchwały Konferencji Biskupów zanim zostaną zastosowane w życiu muszą jednak uzyskać zatwierdzenie Stolicy Apostolskiej. Tak też konferencje Biskupów uzyskały prawo ustalenia, aby postanowienie podjęcia celibatu (w święceniach diakonów, nn. 200, 228, 268, 309 - czy na znak wewnętrznego oddania Chrystusowi Panu przyrzekasz zawsze zachowywać celibat ze względu na królestwo niebieskie, służąc Bogu i ludziom?- Przyrzekam) wyrażane było nie tylko w odpowiedzi na dotyczące tego pytanie, ale również w jakiejś formie zewnętrznej ${ }^{55}$. (Niestety autorowi niniejszego opracowania, mimo poszukiwań, nie jest znany żaden dokument Konferencji Episkopatu Polski regulujący przywołaną kwestię). Dobrowolnie wyrażona wola podjęcia celibatu przez kandydatów do święceń diakonatu wobec zgromadzenia Kościoła w czasie obrzędu święceń diakonów posiada charakter publiczny ${ }^{56}$.

\footnotetext{
${ }^{53}$ Por. F. Lonza, Prerequisites for Ordination, w: Exegetical Commentary on the Code of Canon Law, ed. Á. Marzoa, J. Miras, R. Rodríguez-Ocaña, English language ed. E. Caparros, P. Lagges, vol. III/1, Montreal - Chicago 2004, s. 973-975.

${ }^{54}$ Por. Kongregacja Kultu Bożego i Dyscypliny Sakramentów, Dekret, p. 5 , 29.06.1989, Prot. CD 145/89, w: Pontyfikał Rzymski..., dz. cyt., s. 6. - Warto nadmienić, że w treści niniejszego dekretu zawarta została wzmianka, że obowiązuje on bez względu na wszelkie przeciwne zarządzenia.

${ }^{55}$ Por. Wprowadzenie ogólne, n. III.11.d, w: Pontyfikał Rzymski ..., dz. cyt., s. 14.

${ }^{56}$ Por. Pontyfikat Rzymski..., dz. cyt., n. 176, s. 119.
} 
Biskup diecezjalny decyzję o dopuszczeniu do święceń podejmuje na podstawie osobistej znajomości kandydata ${ }^{57}$ oraz dokumentacji przedstawionej przez dyrektora formacji. Decyzja powinna być wyrażona $\mathrm{w}$ formie dekretu nie później, jak miesiąc przed datą święceń ${ }^{58}$.

Kompetentny przełożony nie powinien jej podejmować, jeśli uprzednio nie zostanie wykluczone istnienie przeszkód i nieprawidłowości do przyjęcia święceń (Por. KPK 1983, kan. 1040-1043) ${ }^{59}$. Oprócz tych wymienionych w kanonach nieprawidłowości i przeszkód należy wziąć pod uwagę również przeciwskazania w dopuszczaniu do święceń, wymienione między innymi w dokumentach pozakodeksowych, takich jak: Wyjaśnienie w sprawie użcia chleba z zawartościa glutenu i moszczu jako materii eucharystycznej Kongregacji Nauki Wiary z dn. 19.06.1995 r. (normy zawarte w niniejszym dokumencie zostały zaaprobowane przez Kongregację dn. 22 czerwca 1994 roku, w czasie zwykłej sesji) oraz Instrukcja nt. kryteriów rozeznawania powołania u osób z tendencjami homoseksualnymi ubiegajacych się o przyjęcie do seminarium $i$ dopuszczenie do święceń Kongregacji Edukacji Katolickiej z dn. 4.11.2005 roku, która została zatwierdzona dn. 31 sierpnia 2005 r. przez papieża Benedykta XVI ${ }^{60}$. Zgodnie z przywołanym jako pierwszym dokumentem, „kandydaci do kapłaństwa, którzy są chorzy na celiachię lub są dotknięci alkoholizmem lub analogicznymi chorobami, biorąc pod uwagę centralne miejsce celebracji eucharystycznej w życiu kapłańskim, nie mogą być dopuszczeni do święceń" "1 . (Kompetencja dyscyplinarna łącząca się z tym za-

${ }^{57}$ Osobista znajomość kandydata zakłada potrzebę spotkania się biskupa z kandydatem bez pośrednictwa jakichkolwiek delegatów.

${ }^{58}$ Ów miesiąc należy liczyć zgodnie z przywołanymi wcześniej zasadami.

${ }^{59}$ Więcej na ten temat można przeczytać w: M. PAstuszko, Nieprawidłowości i przeszkody do święceń (kanony 1440-1049), w PK 2007, nr 3-4, s. 117-228.

${ }^{60}$ Por. Kongregacja Nauki Wiary, Wyjaśnienie w sprawie użycia chleba z zawartościa glutenu i moszczu jako materii eucharystycznej, Prot. N. 89/78, z dn. 19.06.1995 r., cytowane za: Miesięcznik Pasterski Płocki, nr 9/95 s. 419-420; KongREGACJA EduKACJI KatOLICKIEJ, Instrukcja nt. kryteriów rozeznawania powołania u osób z tendencjami homoseksualnymi ubiegajacych się o przyjęcie do seminarium i dopuszczenie do święceń, z dn. 4.11.2005 r. - tłumaczenie polskie za L’Osservatore Romano 5/2006.

${ }^{61}$ Kongregacja Nauki Wiary, Wyjaśnienie w sprawie..., dz. cyt., p. III. d. 
gadnieniem mieści się w kompetencji Kongregacji ds. Kultu Bożego i Dyscypliny Sakramentów ${ }^{62}$. Według norm zawartych w Instrukcji nt. kryteriów rozeznawania powołania u osób z tendencjami homoseksualnymi..., Kongregacja Edukacji Katolickiej, w porozumieniu z Kongregacją ds. Kultu Bożego i Dyscypliny Sakramentów, uznała, że nie można przyjmować do seminarium ani do święceń osób, które praktykują homoseksualizm, wykazują głęboko zakorzenione tendencje homoseksualne lub wspierają tak zwaną „kulturę gejowską", ponieważ osoby takie, w istocie, znajdują się w sytuacji, która poważnie uniemożliwia im poprawną relację do mężczyzn i kobiet. Kongregacja uzasadniając przywołane stwierdzenie, dodała, że nie można w żaden sposób zignorować negatywnych konsekwencji mogących zrodzić się na skutek święceń osób o głęboko zakorzenionych tendencjach homoseksualnych. Według Kongregacji Edukacji Katolickiej należy inaczej traktować tendencje homoseksualne (w odróżnieniu do praktykowania homoseksualizmu, wykazywania głęboko zakorzenionych tendencji homoseksualnych lub wspierania tak zwanej „kultury gejowskiej”), które są jedynie wyrazem przejściowego problemu, takiego jak, na przykład, niezakończony jeszcze proces dojrzewania. Niemniej jednak takie tendencje muszą być wyraźnie przezwyciężone, przynajmniej trzy lata przed święceniami diakonatu ${ }^{63}$. Mówiąc o rozeznaniu zdatności do święceń kandydatów, Kongregacja Nauki Wiary w przywołanej instrukcji stwierdziła, że ważne zadanie w tej kwestii spoczywa na kierowniku duchowym, bowiem reprezentuje Kościół na forum wewnętrznym. Kierownik duchowy ma obowiązek ocenić wszelkie cechy osobowości kandydata i upewnić się, że nie występują u niego zaburzenia natury seksualnej, które są nie do pogodzenia z kapłaństwem. Jeśli kandydat uprawia homoseksualizm, albo wykazuje głęboko zakorzenione tendencje homoseksualne, jego kierownik duchowy, a także spowiednik ma w sumieniu obowiązek odwieść go od ubiegania się o święcenia ${ }^{64}$.

\footnotetext{
${ }^{62}$ Tamże, p. III. e.

${ }^{63}$ Por. Kongregacja Edukacji Katolickiej, Instrukcja nt. kryteriów..., dz. cyt., p. 2.

64 Tamże, p. 3.
} 
Wracając do przerwanego wątku, należy zauważyć, że kandydaci do święceń (jakichkolwiek) muszą przed święceniami odprawić przynajmniej pięciodniowe rekolekcje w miejscu i w sposób określony przez ordynariusza (Por. KPK 1983, kan. 1039). Od tego wymogu biskup diecezjalny może dyspensować w oparciu o normę zawartą w kan. 87 §1 Kodeksu prawa kanonicznego. Zaświadczenie o odbyciu rekolekcji powinno znaleźć się aktach personalnych. (Por. KPK 1983, kan. 1039.) Co się tyczy odbywania rekolekcji, należy pamiętać, że zgodnie z kan. 202 §1 KPK 1983 dzień w prawie oznacza stały czasokres obejmujący 24 kolejno liczone godziny i zaczyna się od północy. A zatem, jeśli rekolekcje zaczynają się rano i kończą wieczorem, to pierwszego i ostatniego dnia nie wlicza się do czasu odbytych rekolekcji.

Po udzieleniu święceń, w specjalnej księdze, przechowywanej w kurii diecezji miejsca święceń, należy zapisać: nazwisko wyświęconego, nazwisko szafarza, miejsce i datę udzielenia święceń (Por. KPK 1983, kan. 1010-1011). Biskup udzielający święceń powinien także każdemu wyświęconemu wydać autentyczne świadectwo otrzymanych święceń (Por. KPK 1983, kan. 1053). Ordynariusz miejsca o fakcie święceń powiadamia także proboszczów parafii chrztu nowo wyświęconych diakonów i praezbiterów, aby mogli zgodnie z kan. 535 §2 KPK 1983 dokonać stosownej adnotacji w aktach chrzcielnych. Na marginesie należy stwierdzić, że niniejsza procedura dokonania powiadomienia proboszcza parafii chrztu nowo wyświęconego alumna przez ordynariusza miejsca wydaje się praktyczna jedynie w przypadku przyjęcia święceń przez duchowieństwo diecezjalne tegoż ordynariusza. Trudno sobie wyobrazić stronę praktyczną tejże procedury w przypadku udzielenia święceń duchowieństwu niediecezjalnemu przez biskupa diecezji (albo biskupa pomocniczego diecezji), której ordynariusz w myśl kan. 1053 KPK 1983 miałby dokonywać powiadomienia; bądź też w przypadku udzielenia święceń duchowieństwu niediecezjalnemu przez biskupa nie będącego zarazem biskupem diecezji (albo biskupem pomocniczym diecezji), na której terenie zostały udzielone święcenia. Rozwiązanie, jakie zostało przepisane w prawie partykularnym Archidiecezji Warszawskiej, zgodnie z którym obowiązek dokonania 
powiadomienia spoczywa na rektorze seminarium, wydaje się znacznie praktyczniejsze.

W Archidiecezji Warszawskiej zgodnie z statutem 313 IV Synodu Archidiecezji Warszawskiej, obowiązek powiadomienia parafii chrztu o przyjęciu święceń prezbiteratu przez nowo wyświęconego spoczywa na rektorze seminarium. Dodatkowo, oprócz proboszcza parafii chrztu, rektor seminarium został zobligowany do powiadomienia proboszcza parafii aktualnego zamieszkania ${ }^{65}$. Według woli ustawodawcy wyrażonej w przywołanym statucie, powiadomienie proboszczów ma dokonać się niezwłocznie po święceniach wg zasady „Ne temere”. Zgodnie z przywołaną zasadą zawartą w Instrukcji Episkopatu Polski o przygotowaniu do zawarcia matżeństwa w Kościele Katolickim p. 99, duszpasterz miejsca przyjęcia chrztu św. nowo wyświęconego alumna ma ścisły obowiązek odnotować fakt przyjęcia święceń na marginesie aktu chrztu w księdze ochrzczonych i przesłać wiadomość o dokonaniu tej adnotacji do rektora seminarium. Zawiadomienie o dokonaniu adnotacji należy dołączyć do dokumentów personalnych nowo wyświęconego. Statut 324 IV Synodu Archidiecezji Warszawskiej precyzuje, że zawiadomienie o przyjęciu święceń powinno zostać wysłane przez rektora w ciągu miesiąca od dnia święceń. Zawiadomienie o dokonaniu adnotacji w uwagach aktu chrztu powinno zostać odesłane w jak najszybszym terminie.

Przepisy szczegółowe Archidiecezji Warszawskiej nie regulują kwestii powiadomienia proboszcza parafii chrztu o fakcie przyjęcia święceń $\mathrm{W}$ stopniu diakonatu. Wobec tego zgodnie $\mathrm{z}$ prawem powszechnym obowiązek powiadomienia spoczywa na ordynariuszu miejsca, jednakże ze względów praktycznych należałoby zastosować w tym przypadku procedurę powiadomienia przepisaną przez prawo partykularne dla dokonania adnotacji faktu przyjęcia święceń w stopniu prezbiteratu.

${ }^{65}$ Prawo powszechne nie zawiera wymogu powiadamiania proboszcza miejsca zamieszkania o fakcie przyjęcia święceń przez mieszkańca. W związku z normą wyrażoną w statucie 312 IV Synodu Archidiecezji Warszawskiej, rodzi się pytanie o to, którego proboszcza miejsca zamieszkania należy powiadomić - stałego, czy tymczasowego? (O zamieszkaniu będzie mowa nieco dalej w tekście.) 


\section{Klerycy pochodzący $z$ diecezji innych niż seminarium, w którym przygotowują się do święceń}

Kilka uwag o dopuszczaniu do posług i święceń alumnów powierzonych formacji seminaryjnej przez biskupów diecezjalnych i przełożonych niebędących odpowiedzialnymi za seminarium, w którym formują się ich klerycy, a także o udzielaniu posług i święceń alumnom niemającym być inkardynowanymi do diecezji biskupa udzielającego posługi bądź święcenia.

$\mathrm{Z}$ zasady alumni przygotowują się w seminariach diecezjalnych diecezji, w których pragną po święceniach kapłańskich posługiwać i być do tychże diecezji inkardynowanymi. W takich sytuacjach nie ma problemu z określeniem, który biskup diecezjalny dopuszcza do: lektoratu, akolitatu, kandydatury, diakonatu, prezbiteratu oraz ich udziela.

W Kodeksie prawa kanonicznego odnajdujemy normę określającą osobę biskupa kompetentnego do udzielenia kandydatury, diakonatu, prezbiteratu. Zgodnie z kan. 1015 kandydat do prezbiteratu i diakonatu powinien być wyświęcony przez własnego biskupa, albo przez obcego biskupa na podstawie dymisoriów udzielonych zgodnie z prawem przez własnego biskupa. W przypadku święceń diakonatu, tych którzy mają być włączeni do kleru diecezjalnego, biskupem własnym jest biskup tej diecezji, w której kandydat ma stałe zamieszkanie, albo diecezji, której postanowił się poświęcić (Por. KPK 1983, kan. 1016).

Kodeks Jana Pawła II precyzuje sposoby nabycia stałego zamieszkania. Należy w tym miejscu zauważyć, że nie można utożsamiać zamieszkania z zameldowaniem. Zamieszkanie stałe nabywa się takim przebywaniem na terytorium jakieś diecezji, które jest połączone z zamiarem pozostania tam na stałe, jeśli nic stamtąd nie odwoła, albo trwało przez pięć pełnych lat (Por. KPK 1983, kan. 102§1). Jak zauważa Sobański powołując się na kan. 201 §1 KPK 1983 ,,przebywanie to obecność fizyczna, trwająca w sposób moralnie ciągły (tempus continuum wg. kan. $201 \S 1$ KPK 1983), motywowana zamiarem zamieszkania (per modum inhabitantis). Nie chodzi o ilość czasu spędzonego w danym miejscu, lecz o traktowanie tego miejsca, jako mieszkanie (,dom”). Nie przerywa przebywania nieobecność fizyczna 
(np. dla wykonywania zawodu, urlop), jeśli nie towarzyszy jej zamiar niepowrotu". Wspomniany autor zwraca również uwagę, że jeśli pozostanie w danym miejscu zostaje uzależnione od warunku zawieszającego, o zamiarze pozostania na stałe może być mowa dopiero $\mathrm{z}$ chwilą spełnienia się warunku ${ }^{66}$. Takim warunkiem zawieszającym, może w przypadku alumnów okazać się przyjęcie, lub nieprzyjęcie święceń diakonatu. Jeśli przebywanie trwało pięć lat (obliczanych wg. KPK 1983, kan. 200-203), z ich upływem nabywa się stałe zamieszkanie, niezależnie od woli przebywającego.

Po określeniu biskupa kompetentnego do udzielenia święceń diakonatu alumnowi mającemu być włączonym przez święcenia do kleru diecezjalnego, rodzi się pytanie o sposób wyrażenia woli przez kleryka o poświęceniu się konkretnej diecezji. Prawo nie reguluje tej kwestii. Wolę tę kleryk może wyrazić w sposób wyraźny w kilku momentach formacji seminaryjnej. Po raz pierwszy może (i powinien) mężczyzna wyrazić swoją wolę poświęcenia się diecezji w podaniu o przyjęcie do seminarium. Po raz kolejny wolę poświęcenia się diecezji alumn może i powinien wyrazić w podaniu: o dopuszczenie do lektoratu, akolitatu, kandydatury, diakonatu. Choć na marginesie należy zaznaczyć, że raz wyrażona wola i nieodwołana jest ciągle aktualna.

Wracając do przerwanego wątku, zgodnie z normą zawartą w kan. 1015 KPK 1983, jeśli chodzi o udzielenie święceń prezbiteratu tym, którzy są włączeni do kleru diecezjalnego, biskupem własnym, który może udzielić święceń bądź wystawić dymisorie, jest biskup diecezji, do której kandydat został inkardynowany przez diakonat. Należy przy tym pamiętać, że przyjmując diakonat alumn staje się duchownym i zostaje inkardynowany do diecezji, dla których posługi został promowany. Członkowie instytutów świeckich przez przyjęcie diakonatu zostają inkardynowani do kościoła partykularnego, dla posługi którego zostali promowani, chyba że na mocy zezwolenia Stolicy Apostolskiej, są inkardynowani do samego instytutu (Por. KPK 1983, kan. $266 \S 1,3)$.

${ }^{66}$ Por. R. Sobański, Pozycja kanoniczna osób fizycznych, w: Komentarz do Kodeksu prawa kanonicznego..., dz. cyt., t. 1, s. 173; T. PAwLuK, dz. cyt., s. 255. 
Przy udzielaniu święceń należy pamiętać o ogólnej zasadzie, że zgodnie z kan. 1017 KPK 1983 biskup udzielający święceń poza własną diecezją musi uzyskać zgodę na udzielenie święceń od biskupa diecezji miejsca udzielenia święceń. Zgody tej nie należy utożsamiać z dymisoriami, o których mowa w dalszej części rozważań.

Z przedstawionych przepisów, trudno jest wprost wywnioskować, który biskup ma prawo podjąć decyzję o dopuszczeniu alumna do święceń diakonatu - alumna, który po święceniach zostanie włączony do kleru diecezjalnego ${ }^{67}$. Z pomocą w wyjaśnieniu tej kwestii przychodzi jednak norma zawarta w kan. 1029 i 1016 KPK 1983 oraz Pismo okólne Kongregacji Kultu Bożego i Dyscypliny Sakramentów, p. 3. Według niej jest nim biskup stałego zamieszkania bądź diecezji, której postanowił poświęcić się kandydat. To właśnie ten biskup ocenia przymioty kandydata zgodnie z normami wcześniej wyrażonymi oraz czy kandydat do święceń jest potrzebny do posługi Kościoła. W przypadku, gdy kandydat do święceń, mający wolę poświęcenia się innej diecezji, jest święcony (albo dopuszczany do święceń) przez biskupa miejsca stałego zamieszkania, biskup miejsca stałego zamieszkania musi mieć pewność, że kandydat do święceń diakonatu - po święceniach - zostanie przyjęty do tej diecezji (Por. KPK 1983, kan. 1025). Ze względów dowodowych wydaje się, że zapewnienie o przyjęciu do diecezji wyświęconego diakona powinno być wyrażone na piśmie. Zgodnie z przywołanymi normami, biskupem podejmującym decyzję o dopuszczeniu do święceń prezbiteratu duchownych diecezjalnych jest biskup diecezji, do której przez diakonat duchowny został inkardynowany.

Skoro już zostało określone, który z biskupów dopuszcza do święceń diakonatu i prezbiteratu duchownych diecezjalnych, oraz udziela wspomnianych święceń, należy postawić kolejne pytanie, który biskup diecezjalny dopuszcza i włącza alumna przez liturgiczny obrzęd do

${ }^{67}$ Chodzi ciągle o przypadek określony nieco wyżej, jako - dopuszczanie do posług i święceń alumnów powierzonych formacji seminaryjnej przez biskupów diecezjalnych i przełożonych niebędących odpowiedzialnymi za seminarium, w którym formują się klerycy - „obcych kleryków” a także o udzielaniu posług i święceń alumnom niemającym być inkardynowanymi do diecezji biskupa udzielającego posługi bądź święcenia. 
grona kandydatów do święceń. Według normy zawartej w kan. 1034 $\S 1$, jeśli chodzi o tych, którzy po święceniach mają być włączeni do kleru diecezjalnego, jest nim biskup stałego miejsca zamieszkania bądź diecezji, której postanowili się poświęcić. Choć prawo nie stanowi, jak należy postąpić, gdy do grona kandydatów do święceń włącza biskup stałego miejsca zamieszkania alumna chcącego poświęcić się innej diecezji, wydaje się uzasadnionym postąpienie zgodnie z kan. $1025 \S 3$ KPK 1983, a co za tym idzie, włączenie go przez liturgiczny obrzęd do grona kandydatów dopiero po uzyskaniu pewności, że biskup diecezji, której pragnie się poświęcić alumn, przyjmie go po święceniach do diecezji.

W odniesieniu do dopuszczenia do posług lektoratu i akolitatu alumnów mających po święceniach być duchownymi diecezjalnymi oraz udzielenia wspomnianych posług, biskupem kompetentnym jest również biskup miejsca stałego zamieszkania oraz diecezji której pragnie się alumn poświęcićc ${ }^{8}$. Co się tyczy udzielenia posług przez biskupa diecezji miejsca stałego zamieszkania alumnom chcącym po święceniach poświęcić się innej diecezji, uzasadnionym wydaje się postąpienie zgodnie z kan. 1025 §3 KPK 1983.

Na marginesie nasuwa się kolejny wniosek - w przypadku alumnów wstępujących do seminarium miejsca stałego zamieszkania, a planujących po święceniach poświęcić się obcej diecezji, decyzję o gotowości przyjęcia po święceniach do tejże diecezji powinien podjąć biskup już w chwili przyjęcia kandydata do seminarium a następnie (dobrze by było), gdyby przed kandydaturą lub diakonatem ją powtórzył. Choć należy zaznaczyć, że raz wyrażona decyzja, trwa do odwołania, chyba, że wcześniej była uzależniona od warunku, który nie został wypełniony.

Po dokonaniu dotychczasowych ustaleń, kolejną ważną rzeczą wydaje się określenie jak należy postąpić, gdy święceń, kandydatury i posług ma udzielić biskup nie na podstawie własnego prawa, czyli inny niż określony w kan. 1016, 1018 KPK $1983^{69}$. Po podjęci decyzji

\footnotetext{
${ }^{68}$ Kongregacja ds. Kultu Bożego i Dyscypliny Sakramentów, Pismo okólne..., p. 1-3.

${ }^{69} \mathrm{~W}$ tym miejscu pragnę jeszcze raz zaznaczyć, że w niniejszych rozważaniach koncentruję się jedynie na alumnach mających być włączonych do kleru diecezjalnego
} 
o dopuszczeniu do święceń przez własnego biskupa (według kan. 1016 KPK 1983) lub przełożonego (według KPK 1983, kan. 1018), kompetentny przełożony wystawia dymisoria dla szafarza święceń zgodnie z kan. 1018-1023 KPK 1983.

Jak zauważa Pastuszko, dymisoria powinny zawierać: imię i nazwisko osoby wystawiającej dymisorie, imię i nazwisko kandydata do święceń, prośbę o udzielenie określonego stopnia święceń, datę i podpis wystawiającego, podpis notariusza. W dymisoriach należy zaznaczyć, lub do nich dołączyć zaświadczenie o zdatności kandydata do święceń. O tej zdatności wystawiający upewnia się w czasie skrutinium. Zgodnie z kan. 1052 KPK 1983 pismo to informuje, że zebrano wszystkie wymagane dokumenty, przeprowadzono badanie zgodnie z przepisami prawa. Jeśli kandydat jest członkiem instytutu zakonnego lub stowarzyszenia życia apostolskiego, dokument ten powinien zaświadczać, że kandydat został definitywnie włączony do instytutu lub stowarzyszenia i jest podwładnym przełożonego wystawiającego dymisorie. Zdaniem Pastuszki w dymisoriach ewentualnie powinna być uczyniona informacja o uzyskanych dyspensach, lub prośba o udzielenie dyspensy, pod warunkiem, że biskup święcący jest kompetentny do jej udzielenia. Jak zaznacza wspomniany autor, powołując się na kodeks, w dokumencie tym może być uczyniona wzmianka o warunkach od spełnienia, których powinno zostać uzależnione udzielenie święceń. Co się tyczy warunków należy pamiętać o tym, że wspomniane warunki mogą wpływać na ważność aktu0 (por. KPK 1983, kan. 39) i ich niespełnienie skutkowałoby nieważnością legalnie wystawionych dymisoriów ${ }^{71}$. Ponieważ są sytuacje, w których udzielenie dymisoriów

i diakonach diecezjalnych. W rozważaniach o dymisoriach mogą pojawić się chwilami wzmianki o święceniu członków instytutów zakonnych lub stowarzyszeń życia apostolskiego, ale tylko o w takiej mierze, jakiej dotyczyłoby to biskupów udzielających im święceń.

${ }^{70}$ Mówiąc o ważności aktu, nie należy mieć na myśli ważności święceń. Na marginesie o ważności święceń można przeczytać w: Z. JANCZEWSKI, Ważność sprawowania sakramentów wtajemniczenia chrześcijańskiego uzdrowienia $i$ święceń $w$ porządku prawnym Kościoła Katolickiego, Warszawa 2011.

${ }^{71}$ Por. M. Pastuszko, Sakrament święceń..., dz. cyt., s. 186-187. 
jest uzależnione od uzyskania zgody lub opinii pewnego kolegium (por. KPK 1983, kan. 587, 1018), która to wpływa zgodnie z kan. 127 kodeksu Jana Pawła II na ważność czynności prawnej, w dymisoriach powinien zostać odnotowany fakt uzyskania opinii lub zgody owego kolegium, aby szafarz święceń nie musiał się domyślać czy przepisy prawa kanonicznego powszechnego i ewentualnie specjalnego przy wystawianiu dymisoriów były przestrzegane.

Dymisorie powinno być zaadresowane na: konkretnego biskupa ściśle określonego (imieniem i nazwiskiem bądź urzędem - np. Abp. Kazimierz Nycz, Arcybiskup Metropolita Warszawski); ewentualnie ściśle określoną grupę biskupów (np. Arcybiskup Metropolita Warszawski i Jego biskupi pomocniczy - należy zwrócić uwagę na spójnik „¡”, „oraz”, gdyż zastosowanie przykładowo spójnika „albo” nie pozwalałoby określić dla kogo dokładnie przekazane są dymisoria, a co za tym idzie - byłby zaadresowane niewłaściwie); $;{ }^{72}$ albo jakiegokolwiek biskupa mającego łączność ze Stolicą Apostolską ${ }^{73}$. W przypadku gdyby szafarz święceń był innego obrządku niż kandydat do święceń, dymisorie byłoby wystawione niezgodnie z prawem, jeśli Stolica Apostolska nie udzieliłaby na nie indultu (Por. kan. 1015 §1-2, 1021 KPK 1983). Gdy szafarz święceń lub kandydat do święceń są obrządku wschodniego należy uwzględniać również przepisy Kodeksu kanonów Kościołów wschodnich.

Należy pamiętać, że biskup rzymskokatolicki, który nie mając do tego tytułu wyświęcił obcego podwładnego bez zgodnych z prawem dymisoriów, albo podwładnego obrząaku wschodniego bez indultu Stolicy Apostolskiej, podlega przez rok zakazowi udzielania święceń, zaś ten kto przyjął święcenia mocą samego faktu jest suspendowany od przyjętego święcenia (Por. KPK 1983, kan. 1333, 1383).

Na marginesie w tym miejscu należy zwrócić uwagę na częste błędy popełniane przy wystawieniu dymisoriów. Zdarza się, że w przypadku członków instytutów zakonnych na prawach papieskich i stowarzyszeń życia apostolskiego na prawach papieskich, kompetentni przeło-

\footnotetext{
${ }^{72}$ Por. W. GóRalski, Kościelne prawo matżeńskie, Warszawa 2006, s. 236-237.

${ }^{73}$ Por. M. Pastuszko, Sakrament święceń..., dz. cyt., s. 200-201.
} 
żeni kierując list do biskupa diecezjalnego, mającego udzielić święceń członkom wspomnianych instytutów bądź stowarzyszeń, proszą biskupa diecezjalnego zamiast o udzielenie święceń o dopuszczenie do święceń. Prawidłowo dymisorie powinien wystawić wyższy przełożony ${ }^{74}$, prosząc biskupa o udzielenie święceń (por. KPK 1983, kan. 1019 KPK).

Kolejnym błędem, z którym możemy się spotkać przy wystawieniu dymisoriów przez wyższych przełożonych dla biskupa pomocniczego jakieś diecezji (np. diecezji ,A”), jest skierowanie dymioriów do biskupa diecezjalnego (diecezji „A”), a nie szafarza święceń. W takiej sytuacji należałoby przesłać dymisorie biskupowi pomocniczemu diecezji „A”, jako szafarzowi święceń, oraz zgodnie z kanonem 1017 KPK 1983 poprosić biskupa diecezjalnego diecezji „A” o zgodę, aby święceń na terenie diecezji „A" mógł udzielić biskup pomocniczy diecezji „A Sytuacja nieco się komplikuje, kiedy biskup pomocniczy diecezji „A” udziela święceń na terenie diecezji „B”. Gdyby biskup pomocniczy diecezji „A” udzielał święceń na terenie diecezji „B” to dymisoria należałoby przesłać biskupowi pomocniczemu, zaś o zgodę zgodnie z kan. 1017 KPK 1983 należałoby poprosić biskupa diecezji „B”.

Przy okazji tematu dymisoriów, pojawia się kolejne pytanie o dokumenty, jakie należałoby przygotować, gdyby biskup pomocniczy diecezji „A” (będący wikariuszem generalnym, lub biskupim diecezji „A") udzielałby na terenie diecezji „A” święceń alumnom mającym być włączonym do kleru diecezjalnego diecezji „A”, albo w przypadku święceń diakonatu - alumnom mającym być włączonymi po święceniach do diecezji „B”, zaś mającym na terenie diecezji „A” stałe

${ }^{74}$ Ponieważ w konstytucjach urząd kompetentnego przełożonego do wystawienia dymisoriów określany jest niejednokrotnie różnymi terminami w zależności od instytutu lub stowarzyszenia, wydaje się koniecznym w dymisoriach zaznaczyć podstawę prawną, na jakiej opiera się wystawiający dymisoria, aby uniknąć wątpliwości po stronie adresata wspomnianego dokumentu.

${ }^{75}$ Sytuacja ta dotyczy nie tylko członków instytutów i stowarzyszeń. Z podobną sytuacją możemy się spotkać, kiedy na terenie jednej diecezji są święceni na diakonów alumni diecezjalni nie mający na jej terenie stałego miejsca zamieszkania i nie planujący się jej po święceniach poświęcić, a także przy święceniach prezbiteratu diakonów inkardynowanych do innej diecezji niż diecezji biskupa diecezjalnego - szafarza święceń. 
zamieszkanie. Można by było zastosować dwa rozwiązania prawne tej sytuacji. Pierwsze rozwiązanie - Biskup diecezji „A” (jako własny biskup diecezjalny alumnów) mógłby zgodnie z kan. 134 §3, 137, 479 §1-2 kodeksu Jana Pawła II udzielić specjalnego zlecenia swojemu biskupowi pomocniczemu, aby ten na terenie diecezji, której jest ordynariuszem (jako wikariusz generalny lub biskupi), wyświęcił alumnów. Na mocy specjalnego zlecenia biskup pomocniczy mógłby też dopuszczać alumnów do święceń, kandydatury, posług.

Drugie rozwiązanie to wystawienie biskupowi pomocniczemu dymisoriów (zgodnie z kan. 1016, 1018 KPK 1983) oraz zgodnie z kan. 1017 kodeksu Jana Pawła II zgody na udzielenie święceń.

W przypadku kandydatury i posług należałoby zastosować analogiczną procedurę do rozwiązania pierwszego, z tym że nie trzeba wystawiać zgody o której w kan. 1017 KPK 1983, gdyż ona dotyczy tylko święceń.

\section{Podsumowanie}

Jak zauważył Jan Paweł II w posynodalnej adhortacji apostolskiej Pastores dabo vobis n. 41, ,powołanie kapłańskie jest darem Bożym danym nie tylko konkretnej, powołanej osobie, ale jest to również dar dany całemu Kościołowi"76. Zatem odpowiedzialnym za narodziny i dojrzewanie powołań kapłańskich jest cały Kościół, którego żywotność zależy w dużej mierze od jakości kapłanów, a ta z kolei od formacji, jaką otrzymują przed przyjęciem święceń oraz w czasie pełnienia posługi kapłańskiej. Wyrazem tej świadomości i odpowiedzialności Kościoła za proces formacyjny, jak zostało to ukazane w niniejszym opracowaniu, jest między innymi wielkie zaangażowanie: biskupa, zespołu moderatorów, wykładowców, spowiedników, proboszczów, duchownych, wspólnoty parafialnej - jednym słowem - wszystkich wiernych, w proces rozeznania zdatności alumna do przyjęcia sakramentu święceńn ${ }^{77}$. Rozeznaniu zdatności do święceń, na różnych etapach formacji seminaryjnej - już od momentu przyjęcia do seminarium - towarzyszy złożony proces informacyjny, w większości mający

\footnotetext{
${ }^{76}$ Jan Pawee II, Pastores Dabo Vobis, n. 41.

${ }^{77}$ Por. RISP, Wstęp.
} 
swoje odzwierciedlenie w bogatej dokumentacji, stanowiącej część akt personalnych alumna, a później duchownego. Ustanowienie w posłudze lektora i akolity, włączenie do grona kandydatów do święceń oraz udzielenie święceń diakonatu i prezbiteratu każdorazowo poprzedzone jest wydaniem zgodnie z przepisami prawa kościelnego przez biskupa diecezjalnego dekretów, w których potwierdzona zostaje wola biskupa dopuszczenia alumna do posług, kandydatury oraz święceń.

\section{Procedures for reception of priest and deacon ordination}

The sacrament of order is not administered primarily for the personal sanctification of those who receive it, but to serve the Church as sacred minister. The Article presents the decision making process undertaken by the diocesan Bishop when deciding upon the maturity/readiness of a candidate to receive presbyter orders - from the moment he enters the Seminary till the day of receiving the sacrament. It lists documents accompanying the newly ordered presbyter and can be a help for those supporting the Bishop when deciding upon who should be promoted to the ministry of lector, acolyte and become a priest. The author focuses mostly on the legal aspect of the matter concentrating on the alumni incardinated to the diocese. 